\title{
Child Abuse in Pakistan-Current Perspective
}

\author{
Aisha Mehnaz* \\ Department of Medical Education, College of Physicians and Surgeons of Pakistan, Karachi, Pakistan.
}

It's not been long that the case of Baby Zainab from Qasur, a city in Punjab made the headlines in the media. Prior to this incidence cases of sexual abuse of over 200 children from the same city created an uproar in the media and in the country. In the past few years there has been an upsurge in the cases of child abuse reported in the media. The concerns over rising incidence of child abuse and neglect has received global attention. A number of national and international organization have shown serious concerns and are demanding strict measures to tackle the issues of child protection.

\section{DEFINITIONS OF CHILD ABUSE}

There is no consensus on the definition of child abuse, neglect and violence. There exists a lot of ambiguity in its definition; on several occasions the three terminologies are used interchangeably. For some the term violence is limited to the use of physical force only while others consider verbal and emotional abuse too, as form of violence.

Opinion wavers as to whether aggressive behaviors like bullying, mugging, mobbing or severely detrimental deprivation can be considered synonymous with violence or abuse, or whether it represents different shades of the same spectrum.

However, the consensus definitions for are as follow:

\section{Child Abuse}

In 1999, the WHO consultation on child abuse prevention drafted the following definition of child abuse: "Child abuse or maltreatment constitutes all forms of physical and or emotional ill treatment, sexual abuse, neglect or negligent treatment, or commercial or other exploitation, resulting in actual or potential harm to the child's health, survival, development or dignity in the context of a relationship or responsibilities, trust or power" $[1,2]$.

Maltreatment of children is a term used for both acts of commission and omission. The former is the use of abusive words or actions that results in actual or potential harm to the child. The latter i.e. acts of omission on the other hand is a form of neglect, where the care taker/s of a child fails to provide for the basic physical, emotional, or educational needs of the child .It also encompasses protection from any

*Address correspondence to this author at the Konpal, Child Abuse Prevention Society, 4/N Block 6 PECHS, Karachi, Pakistan.

E-mail: aishamehnaz@hotmail.com physical harm $[3,4]$. The abusive act can be performed by an individual e.g. a parent or at institutions like in hostels or schools or during processes like during war or famine. All damages the prospects of healthy development of a child into adulthood.

\section{Child Neglect}

It is inattention or omission on the part of part of care givers to provide for the development of the child in all spheres; health, education, nutrition, emotional development, shelter and safe conditions in the context of resources available to the family and care takers. A simplified definition is "child neglects occurs when a child's basic needs are not actually met" [5]. In almost $80 \%$ neglect are caused by parents [6].

\section{TYPES OF CHILD ABUSE AND NEGLECT}

Child abuse can take many forms:

\section{Physical Abuse}

The World Health Organization (WHO) defines Child Physical Abuse as any act that causes physical harm to the child. This may take the form of actual interaction or lack of interaction by a person in charge of the child to protect $\mathrm{him} / \mathrm{her}$ from actual or potential harm. The type of injuries includes severe beating, shaking, burns, fractures, attempted suffocation or strangulation or abusive use of drugs to a child or adolescent.

\section{Child Sexual Abuse (CSA)}

CSA is the involvement of children in sexual activity which they cannot fully comprehend as they are developmentally immature and unprepared for it. The consent of the child has no moral or legal implications [7]. In CSA the exposure of children to sexual act is inappropriate for child's age and psychosocial development. Sexual abuse can occur with or without physical contact.

Without Physical Contact: includes passing of sexual comments or verbal sexual abuse, exhibitionism, masturbation, pornography and voyeurism;

With Physical Contact: Includes kissing, hugging or touching in a sexual way, fondling, oral sex, anal or vaginal penetration, molestation (attempted rape or sodomy). It may take the form of: 


\section{Commercial Sexual Exploitation of Children}

It is the use of children for prostitution and /or pornography. There are strong possibilities of the commercial exploitation of children who are used as child labor, in armed conflict, as child soldiers or as suicide bombers.

\section{VIOLENCE}

Violence as defined by The Concise Oxford Dictionary is an unlawful exercise of physical force. Whereas World Health Organization defines it as, the intentional use of physical force or power against oneself, another person, or against a group or community. This has a high likelihood of injury, death, psychological harm, maldevelopment and or deprivation.

Another definition offered by Olweus [8] describes violence as an aggressive behavior where the perpetrator uses an object (his own body or a weapon) to inflict injury or discomfort to an individual.

\section{TYPES OF VIOLENCE}

There are four modes of violence, each with its own subtype. This includes physical, sexual and emotional violence. Moreover, violence arises indirectly from deprivation. In addition to these, there are three sub-types, which are classified as:

1. Self-Directed Violence: It is the violence in which the victim and the perpetrator is the same individual; this includes self-abuse or self-mutilation and suicide.

2. Collective Violence: It is the violence committed by large groups of individuals, and can be subdivided into social, political and economic violence.

3. Interpersonal Violence: Refers to violence between individuals, and is subdivided into. Family and intimate partner violence: this includes child maltreatment, partner violence, and elder abuse, and community violence: includes acquaintance and stranger violence and includes youth violence, assault by strangers, violence related to property crimes, and violence in workplaces and other institutions.

\section{Bullying}

Opinion wavers as to whether aggressive behaviors like bullying, mugging, mobbing or severely detrimental deprivation can be considered synonymous with violence or abuse, or whether it represents different shades of the same spectrum.

The extent and characteristics of bullying vary in different environs and societies. For example verbal abuse or bullying may be unacceptable in one society or country, but may be acceptable or considered weakness of human nature or behavior in another. The response to bullying differs even in domestic or professional environments, such as office or school. In the school environment, bullying is recognizable when it includes hitting, kicking, pushing or shoving around, or threatening the child, or spreading lies or false rumors about him or her; on occasion, children may make unpleasant or mean sounds, and thereby try to make other students hurt him or her [9]. Bullying also includes cyber and racial bullying in addition to more common type of physical and sexual bullying.

\section{PREVALENCE OF CAN}

Violence, Child Abuse and Neglect (CAN) are of global prevalence. Violence is not affected by area, ethnicity, country, religion and gender; it occurs across all socio-economic classes and they remain under-reported issues everywhere.

Globally, 500 million to 1.5 million children suffered violence every year, 73 to 150 million girls are subjected to abuse every year.

In the USA, there are more than 3 million reported cases of CAN. More than 2,000 deaths and 18,000 permanent disabilities happen every year because of CAN in the USA, where 1 in 4 girls, and 1 in 7 boys are sexually molested in childhood. The number of children less than five years of age dying due to CAN is far more than children dying from accidents. Common types of CAN include Physical Neglect (64.1\%), Physical Abuse (16\%), Sexual Abuse (8.8\%) and Emotional Neglect (6.6\%). Nearly $80 \%$ abusers were parents [10].

The situation is equally gloomy in our neighboring countries. In New Delhi, the rate of child abuse is over $83 \%$. More than $72 \%$ were boys and $65 \%$ were girls. About $89 \%$ of the crimes were perpetrated by family members [11].

In India, a neighboring country with similar socio cultural background reported that two thirds children are beaten at home or school every year, $52 \%$ admitted some form of sexual abuse [12].

Sri Lanka, at one time had more than 40,000 children involved in prostitution. Most children were used by western pedophile sex tourists. In year 2006 alone, 549,000 foreign tourists visited Sri Lanka; the projected figures for 2010 were more than one million. The authorities were concerned that with such an exponential increase in number of foreign tourist, and the pedophilic sex industry will flourish more [13].

In Pakistan, no official data exists on various types of CAN. According to unofficial report, $15-25 \%$ children are sexually abused in Pakistan [14]. In Karachi 88.7\% of school children reported physical abuse; $17 \%$ of 300 school children in Rawalpindi/ Islamabad were sexually abused ( 1 in 5 boys and 1 in 7 girls), $72 \%$ of the victims/survivors who were abused were below the age of 13 years. In $80 \%$ of cases, the abuser is 
a close acquaintance $[15,16], 20,000-40,000$ children are engaged in prostitution in Pakistan. Commercial sexual exploitation of children (CSEC) is more common than any other form of exploitation in Pakistan [17].

Sahil an NGO, monitored 91 National and local newspapers in which a total of 3445 cases of child abuse were reported in the year 2017 [18]. Among the cases reported, there were more than 1000 cases of rape and sodomy. They also reported a 9\% increase in reported cases of murder after the sexual abuse. Of these only $72 \%$ cases were registered in police and in the remaining cases the police refuse to register the cases.

This should be the matter of concern for all of us. On the one hand parents have little faith on the Law Enforcing Agencies (LEA) in Pakistan on the other hand those who muster courage to approach LEA and desire to lodge an First Information report (FIR) are discouraged by the police or were entangled in the rigmarole of launching the FIR. Thus precious time is lost. Without FIR, the police surgeon refuses to examine the unfortunate victim of abuse. In case of children not only the chemical evidence (semen analysis e.g.) is lost, the physical healing is also very rapid and the signs of physical violence if any begin to disappear very rapidly thus making it impossible for the examining doctor to reach the correct diagnosis.

\section{CHILD PROTECTION}

Child protection is a concept that aims to safeguard children from Economic exploitation, physical and sexual abuse, and effects of war, neglect, abandonment, maltreatment and Discrimination. It also includes provision of proper care and /or rehabilitation for vulnerable children. Child Protection is about "protecting every right of every child".

Pakistan is both nationally and internationally committed to fully protect the rights of its children. It has ratified the United Nations Convention on the Rights of the Child in 1990 which is the most comprehensive document enshrining all fundamental rights of children. The Constitution of Pakistan lays out a range of rights in regard to children. The first goal of National Vision 2025 is "Putting People First, Development of Human and Social Capital". This can be best achieved by ensuring empowerment and human resource development processes starting at birth and carried through childhood and adolescence. The State bears the primary responsibility to create a preventive and protective environment for children through legislation, policymaking and institutional reform.

It is now over a quarter of century that Pakistan signed the CRC [19]. According to CRC the state has to develop a child protection system to ensure optimum child development and protection. Conventions required legislation to make the CRC law of the land. Till date, Pakistan has no comprehensive children acts or enabling law with regard to the CRC, as a result the Convention cannot be directly applied in the courts.

Relevant legislation on child protection like, Child Protection (Criminal Laws Amendment) Bill, 2009The Child Marriages Restraint (Amendment) Bill, 2009, Juvenile Justice System Ordinance, 2000 etc. are in its various stages of implementation.

Sindh however, has made some progress and a number of legislation have been approved which include Sindh Child Protection Authority Act, 2011, Child marriage act, child corporal punishment act [20-23] etc.

It is thus imperative that due attention is paid to the legislation related to child protection and its enforcement.

Since, the child Abuse is multi factorial in nature, a multi-dimensional approach is needed for its eradication [24], identifications of high risk situations and families, development of outreach programs, identification and empowerment of affected families, setting up of help line and home visiting programs, improving the competencies of service providers and inclusion in education program and curriculum are some measures needed in addition to strict enforcement of legislation and strengthening of law enforcing agencies against the perpetrators of criminal offence against children.

\section{CONCLUSION}

Pakistan still lacks a legal definition of child abuse, neglect or violence (CAN \& violence). In most of the instances a definition put forward by the World Health Organization is being followed. There exist no official source of data on CAN\& violence. Mandatory reporting does not exist [25]. Although, a number of action plan, bill and act are in their various stages of approval and implementation, still Pakistan has far to go in child protection. Being signatory to CRC the prime responsibility lies with the state, but the parents and society need to show their commitments and responsibility too.

"There is no trust more sacred than the one the world holds with children. There is no duty more important than ensuring that their rights are respected, that their welfare is protected, that their lives are free from fear and want and that they can grow up in peace."

\section{CONFLICT OF INTEREST}

Declared none.

\section{ACKNOWLEDGEMENTS}

Declared none. 


\section{REFERENCES}

[1] World Health Organization report of the consultation on Child Abuse Prevention. 1999; Available at: http://apps.who.int/iris/handle/10665/65900

[2] World Health Organization. Child abuse and neglect by parents and other caregivers. Available at: http://www.who.int/violence_injury_prevention/violence/glo bal_campaign/en/chap3.pdf [Retrieved June 08, 2018].

[3] Herrenkohl RC. The definition of child maltreatment: From case study to construct. Child Abuse Negl 2005; 29(5): 413-24. doi:10.1016/j.chiabu.2005.04.002. DOI: 10.1016/j.chiabu.2005.04.002

[4] Children's Bureau, Administration for Children and Families, U.S. Department of Health and Human Services. Definitions of child abuse and neglect in federal law. Available at: Childwelfare.gov. [Retrieved June 08, 2018].

[5] Mehnaz A. Child neglect: Wider dimensions. Chapter 12. In: Child Abuse and Neglect: Challenges and Opportunities. New Delhi: Jaypee Brothers Medical Publishers Ltd. 2013; pp. $100-9$.

[6] Children's Bureau, Administration for Children and Families, U.S. Department of Health and Human Services. Child Abuse and Neglect Statistics. Available at: http:/www.childwelfare.gov/systemwide/statistics/can.cfm [Retrieved June 09, $2018]$.

[7] World Health Organization, Violence and Injury Prevention Team \& Global Forum for Health Research. Report of the Consultation on Child Abuse Prevention. Geneva: WHO 1999; pp. 13-7. Available at : http://apps.who.int/iris/handle/10665/65900

[8] Olweus D. Peer harassment: A critical analysis and some important issues Peer harassment in school: The plight of the vulnerable and victimized. In: Juvonen J, Graham S, Eds. Peer Harassment in School. New York: Guilford Publications 2001; pp. 3-20.

[9] Salmivalli K, Lagerspetz K, Björkqvist K, Osterman, Kaukiainen A. Bullying as a group process: Participant roles and their relations to social status within the group. Aggress Behav 1996; 22: 1-15.

DOI:10.1002/(SICI)1098-2337(1996)22:1<1::AID-AB1> 3.0.CO;2-T

[10] Child Welfare Information Gateway. Child Abuse and Neglect Statistics Available: http://www.childwelfare.gov/systemwide/statistics/can.cfm [Retrieved July 08, 2018].
[11] Srivastava RN, Seth R, Niekerk JV. Child Abuse and Neglect: Challenges and Opportunities. India: Jaypee Brothers 2013.

[12] Ministry of Women and Child Development, Government of India. Study on child abuse in India. Available at:wed.nic.in/childabuse.pdf [Retrieved June 20, 2018].

[13] UNICEF. Zero tolerance for child sex tourism in Sri Lanka. Available at: www.unicef.org/media [Retrieved June 18, 2018].

[14] The commercial sexual exploitation of children in South Asia: Developments, progress, challenges and recommended strategies for civil society. 2014; Available at www.ecpat.net [Retrieved June 20, 2018].

[15] Save the Children Sweden, Pakistan Programme. A situation analysis of CSEC in Pakistan by working group against child abuse against CSA/E 2004. 2009; Available at: http://sahil.org/wp-content/uploads/2014/10/CSEC.pdf

[16] Kane J. Sold for sex (Aldershot: Arena 1998). Millennium; J Int Stud 1998; 27: 1095-7.

[17] SPARC NGO Report. Child trafficking and abduction. 2015; Available at www.sparcpk.org [Retrieved July 03, 2018].

[18] Sahil NGO Report. Cruel Numbers, letting you know the reality. 2017; Available at: www.sahil.org

[19] OHCHR. Convention on the Rights of the Child. Available at: https://www.ohchr.org/Documents/ProfessionalInterest/crc.pdf [Retrieved July 06, 2018].

[20] Jelani A. Punjab Child Protection Law. Available from https://www.dawn.com/news/1388805 Dawn. [Retrieved July 06, 2018].

[21] The Sindh Child Protection Authority Bill. 2011. Sindh Act No: XIV of 2011. Available at: www.pas.gov.pk/uploads/acts/Sindh\%20Act\%20No.XIV\%20of\%202011.pdf

[22] Provisional Assembly of Sindh. Sindh child marriage restraint bill. 2013; Sindh laws.gov.pk/setup/publications/PUB-13-000734.pdf

[23] The Sindh Prohibition of Corporal Punishment Act, July 26, 2017. Available at: https://www.dawn.com [Retrieved July 08, 2018].

[24] Mehnaz A, Shah N, Mala A, et al. Psychosocial determinants of nutritional neglect in a developing country. J Coll Physicians Surg Pak 2014; 24(5): 335-9.

DOI: 04.2014/JCPSP.335339.

[25] Tufail M . Child protection in Pakistan. Int J Child Health Hum Develop 2008; 2 (11): 225-8. 